\title{
Editorial
}

\section{Protest protections, protest problems? Reflections from across the spectrum}

http://dx.doi.org/10.17159/2413-3108/2017/i62a4309

This issue of South African Crime Quarterly is a special issue focusing on protest. It is guest edited by Kelley Moult of the Centre for Law and Society at the University of Cape Town.

Protest is central to citizens' exercise of their rights the world over. A quick scan of this week's news alone (mid-November 2017) shows that residents barricaded roads in Steenberg, Bapong, Walmer, and the Trans-Kalahari Corridor against social housing evictions, unpaid wages, lack of services and other social ills. A newspaper in India ran blank editorial pages to protest the murder of a journalist. Zimbabweans took to the streets to demand that the University of Zimbabwe rescind Grace Mugabe's PhD, to call for Robert Mugabe's resignation, and to celebrate the end of his 37-year authoritarian rule. So-called 'Dreamers' sat down in the parade route during the Macy's Thanksgiving Parade against immigration policy in the United States. Bayern Munich fans threw fake money onto the football pitch to protest against high Champion's League ticket prices.

In South Africa, protest is woven through our history and politics - so much so that the right to protest is a protected right under the country's Constitution. And while post-apartheid democracy should arguably have reduced the impetus for protest, we have instead seen a proliferation of civil disobedience: against service delivery failures, against fees for tertiary education, against corruption, farm murders, fracking and even against our president. These protests have provided a vivid illustration of the clash between institutions and the state on the one hand, and their respective communities on the other. Protesters have been arrested and criminalised, some have been injured and killed at the hands of state police and private security forces. Institutions have turned to the courts for relief against protesters, pushing for orders and prohibitions that many view as increasingly draconian. While activists view protest as an important tactic to agitate for change, and have engaged more creative and visible ways to push their agendas, its moral justification has been widely criticised in public discourse, given its often violent nature.

Andrew Faull's editorial of a year ago notes that 'South Africans' tertiary education, prosecutorial and political landscapes have been shaken, perhaps irrevocably. And while we cannot predict how it will all turn out, change is certainly afoot.' His words remain true, and the articles in this bumper issue of SACQ illustrate the ways that academics, activists, lawyers and practitioners are engaging with questions of protest and response.

Two articles in the collection address the law on protest, and raise questions about the ways in which this right is being obstructed and suppressed, and protesters criminalised. Lisa Chamberlain and Gina Snyman survey the protest landscape through the lens of the public interest legal sector, 
and question, through the experience of Right2Protest, the ways in which court processes are being used as tools with which to quash protest activities. They argue that the law has in itself become a site of contestation, and focus on punitive use of process requirements, the use of interdicts, the abuse of bail procedures, and heavy-handed state responses as evidence of their experience. Extending the focus on one of these themes, Jameelah Omar uses the Social Justice Coalition's challenge to the Regulation of Gatherings Act (RGA) to highlight the controversies around the Act's regulatory provisions. She argues that the case is an important litmus test of the courts' appetite for protecting or constraining the right to protest, and concludes that the Act requires scrutiny and revision in respect of its scope, definitions and processes.

The education sector has seen three years of rolling protest action, arguably the most visible being the \#FeesMustFall campaign that played out at universities across the country, but which has stretched into high schools and primary schools too. Two articles focus on protest related to the right to education - both looking at the right to basic education. Nurina Ally argues that the current legal framework on protest fails to protect and enable children's right to protest, and uses the case of Mlungwana and Others $v$ State and Others to show how the criminalisation of peaceful protest not only violates the state's responsibility to respect, protect and fulfil the right to protest but also specifically fails to take into account the best interests of children - a 'special interest group with particular needs'. She argues that, in addition to removing criminal sanctions for protest, a proper response by the state requires training police in managing protests involving children, and revising administrative requirements that are directed to facilitating the right to protest, rather than scuppering it. Focusing on the South African Schools Act, Ann Skelton and Martin Nsibirwa show how the constitutionally protected rights to protest and to basic education are in tension with each other. They illustrate the complexities of implementing provisions that create criminal accountability in the context of protest, referring to parents' decisions to keep children out of school. These authors argue that while the focus on holding protesters accountable under criminal law may be desirable, the proposed amendments to the Schools Act do not resolve the practical tensions that exist in balancing the rights to protest and to education.

Tsangadzaome Mukumba and Imraan Abdullah turn their attention to the administrative aspects of protecting the right to protest. These authors, from the Legal Resources Centre and the South African History Archive respectively, teamed up to submit a series of Promotion of Access to Information Act (PAIA) requests to municipalities across the country to test how easily accessible information is on where and how to submit a notice of gathering, as required by the Regulation of Gatherings Act. They followed this initial wave of PAIA applications with another set of requests for records relating to public order policing regulations and training. Not only do their results show how difficult it is to access the relevant information, and how uneven compliance is across the country, but they also argue that the government's unwillingness to provide easy access to the information required by protesters to ensure compliance amounts to active resistance to enabling the right to protest. They conclude with a series of recommendations based on international best practices that they hope will foster proactive disclosure of information by municipalities, and suggest statutory reforms to both the RGA and PAIA to this end.

The collection then turns to questions of public opinion on protest. A pair of articles by researchers at the Human Sciences Research Council and the University of Johannesburg focus on the public's views on the policing of protest, and on their attitudes to different forms of protest. Both based 
on nationally representative survey data, the first article, by Roberts et al., asks questions about the public's evaluation of police performance in dealing with protests, and whether the police's use of force in these situations is justifiable. The article argues that the public's perceptions of the policing of protest are negative on the whole. People who are more supportive of police use of force in maintaining public order are more likely to approve of the police's response to protest, although roughly a third of South Africans feel that the police are never justified in using force in these situations. These findings are important, given the levels of protest experienced in the last 10 years, and the mounting tensions with the police and other state institutions that are tasked with regulating and responding to protest. The second article, by Bohler-Muller et al., focuses on patterns of support for different forms of protest action across various socio-demographic and geographic variables. Surprisingly, the authors find no considerable differences across age, gender, race and class in the public's support for protest, although people are more likely to support protest if they think it will be successful. Their data also suggest that people have become more supportive of violent protest over time. The authors raise important policy questions based on this finding: more support for more violent protest, based on its perceived efficacy, has important consequences for the job that law enforcement agencies have in responding appropriately.

Our case note in this issue turns again to the tertiary education protest space and to \#FeesMustFall specifically. Safura Abdool Karim and Catherine Kruyer undertake a deft analysis of Rhodes University $v$ Student Representative Council of Rhodes University, and focus on the ways in which litigation seeking to interdict protest actions had a chilling effect on students' rights to protest. The authors illustrate the challenges experienced at Rhodes University, and problematise the use of over-broad provisions of the interdict that, among other things, prevented two individuals from disrupting lectures and tutorials.

Finally, our issue comes full circle with a review by Patrick Bond of Jane Duncan's work on protest material that provides a theoretical foundation for many of the authors in the collection. Tracing the arc of increasing paranoia and securitisation by the state, beginning in the early 2000s, and increasingly repressive policing tactics in response to protest, Bond turns to Duncan's most recent book, Protest nation. Based on an impressive data set of protests across South Africa, Duncan's work explores the diverse examples of protest, and interrogates the idea of the 'popcorn protest' as seemingly sporadic flare-ups, arguing instead that this characterisation belies much deeper levels of organisation. Bond finds that Duncan's analysis 'fails to grapple fully with the dangers of localism' and provides, in his view, a limited perspective on state failure.

The collection presents, we hope, a varied and nuanced take on the plethora of ways that protest remains both settled and contested, protected and stymied, across the spectrum of issues.

\section{Thanks}

Andrew Faull noted in his editorial in our last issue that the September edition of SACQ would be his last as editor. The Centre for Law and Society is delighted to have taken over the reins of SACQ. We recognise the enormous value of the journal - to the academy and to the field of practitioners, and in bridging the gap between those two constituencies. We are proud to continue in the footsteps of our predecessors, Andrew Faull and Chandré Gould, whose commitment to building the journal, to publishing excellent scholarship and developing new voices makes it easy for our team to continue their efforts. 
Our team is profoundly grateful to Andrew for his thorough, skilful and (perhaps most importantly) patient guidance during the production of this edition. Learning the ropes of peer review processes, back-end production schedules and navigating the foibles of submission portals have certainly been a steep learning curve for us, but Andrew's support has ensured that we feel prepared for the task ahead, and - indeed - that this December edition comes out on time.

\section{Introducing the new editorial team at SACQ}

Finally, I would like to introduce the Centre for Law and Society (CLS) and the team.

The Centre is an innovative and multi-disciplinary hub located in the Law Faculty at the University of Cape Town. It strives to be a place where scholars, students and activists engage critically with, and work together on, the challenges facing contemporary South Africa and Africa at the intersection of law and society. Through socio-legal research, teaching, and critical exchange, the Centre aims to shape a new generation of scholars, practitioners and activists working at the law and society interface, and to build the field of responsive and relevant legal theory, scholarship and practice.

CLS is founded on a culture of inclusivity and team work that we think makes the fit with SACQ especially good. Diversity - of people and viewpoints - is a priority, as we seek to foster collaborative learning and encourage new ways of thinking and doing. We view the editorship of SACQ as an extension of this ethos, and welcome the challenge of working with authors and reviewers to develop excellent scholarship and to encourage engagement across the academia/practice divide. The core members of our team are as follows:

Kelley Moult is the CLS Director. Kelley has 15 years' experience of working on gender, law reform and implementation. Her recent research includes regionally-focused projects on child marriage, sexual health and reproductive rights in Southern Africa, as well as the intersection of Western and traditional justice systems in terms of gender-based violence. Kelley's teaching in the faculty is strongly focused on bringing current research into the classroom, and on fostering new generations of socio-legal scholars.

Diane Jefthas is Deputy Director of CLS. Her research focus over the past few years has been investigating the 'pathways' that rural citizens utilise to access justice after being a victim of crime, and the roles played by families, traditional leaders and state structures in assisting complainants in finding resolution. Diane has a particular interest in transformative pedagogies and the transition from resource-constrained school environments to university.

Nolundi Luwaya is a researcher at CLS. She has worked extensively with rural community-based organisations and NGOs on issues connected to citizenship rights, land rights and nuanced understandings of customary law within our constitutional democracy. Nolundi has a particular interest in the struggles and strategies of women living in rural South Africa, and what these strategies for transforming their particular circumstances can teach us about transformation and change on a societal level.

Vitima Jere is the Hub assistant for CLS. Her work in the Centre focuses on creating supportive spaces in the faculty for debates around critical socio-legal issues and where scholars and activists can engage in critical thinking and writing. Her research interests include international trade law and its impact on how national environmental policies are shaped. 